\title{
Service Quality in Education at Addis Ababa University: The case of the Faculty of Business and Economics Extension Program
}

\author{
Tewodros Wuhib ${ }^{1}$
}

\begin{abstract}
Despite the fact that tertiary level education has been immensely operational, maintaining quality education has become a challenge in Ethiopia. This paper is trying to find out the problem related to service quality in education at Faculty of Business and Economics of Addis Ababa University (Accounting, Economics, Management, Public Administration and Informatics), specific to the extension program. The servqual model is used as an instrument methodology to measure the service quality vis-à-vis Tangibles, Reliability, Responsiveness, Assurance, and Empathy. Primary data pertaining to the research was collected from randomly selected students' drawn from the five departments' under Faculty of Business and Economics. The findings of the study show that except for responsiveness, all the remaining parameters exhibited positive responses from the students. The responsiveness of the Faculty of Business and Economics for evening students is low. But, the students' replied that the faculty is reliable, shows good empathy, good service assurance and tangible. However, some of these items in construct show negative responses. The faculty has to use its resources to improve the problems identified in certain items in the constructs of this research. The study is limited to measure the service quality of the Faculty of Business and Economics extension program. The finding of the study however, may not represent the entire performance of the University. The recommendations and suggestions of this research would serve as a foundation to reinforce the relevance and crucial role that the service quality plays towards the performance of the University.
\end{abstract}

Keywords: Responsiveness, Reliability, Empathy, Assurance and Tangibles

DOI: https://dx.doi.org/10.4314/ejbe.v6i1.3

${ }^{1}$ Lecturer, Department of Management, Addis Ababa University, Email: wuhibteddy@gmail.com 
Service Quality in Education

\section{Introduction}

A service can be defined as: "any act or performance that one party can offer to another that is essentially intangible and does not result in the ownership of anything (Kotler, 1999). The main purpose of service rendering organization is to make the intangible offer tangible through an attempt to meet the customer expectation.

Customers are the sole owners of today's business. That is, the company shall tailor all their activities towards meeting and satisfying their needs. How the company's satisfied and outperforms competition is a critical issue where every service rendering organization must focus on. Only customer focused organizations are striving in developing a long-lasting business relationship with their customers for sustainable growth and development.

In the management context, the word quality can be used to refer to different things: accordance with the requirements, adequacy of use, prevention of losses, or how to answer to or to exceed consumer expectations (Parasuraman, Zeithaml and Berry, 1985, 1988).

The main reason to focus on quality is to meet customer needs while remaining economically competitive at the same time. This means satisfying customer needs is very important for the enterprises to survive. The outcome of using quality practices is: Understanding and improving operational processes; identifying problems quickly and systematically; establishing valid and reliable service performance measures; and measuring customer satisfaction and other performance outcomes

Customers do not perceive quality in a uni-dimensional way but rather judge quality based on multiple factors relevant to the context. Similarly, the service qualities have been identified five specific dimensions as criteria by which interaction, physical environment, and outcome quality may be judged. These five dimensions include: Tangibles; Reliability; Responsiveness; Assurance; and, Empathy; (Parasuraman, Zeithaml and Berry, 1988).

These five dimensions represent how customers' organize information about service quality in their minds. Thus, in measuring the service quality and the level of satisfaction, the gap between the perceived value of service by the customers and the actual service rendered by the organization must tally. 
Service Quality in Education

The research is trying to investigate the service quality performance level of the FBE to its students. That is, it attempts to address the service quality from the review of the related literature; the perception of customers towards receiving quality service, etc. Thus, it incorporates the views of FBE students who have a direct contact with the service, the FBE renders.

The main motivation behind undertaking this research is due to the fact that students interact with departments for certain services, like: advising, add/drop; complaints, etc. Observing their complaints triggers the need to undertake the research in order to substantiate with valid and scientific findings for the betterment of the service, FBE renders to its students.

The main objective of the study is to measure the service quality of FBE through the use of the five constructs (Reliability; Responsiveness; Assurance; Empathy; and Tangibles) designed by (Parasuraman, Zeithaml and Berry, 1988) to measure the satisfaction and dissatisfaction of the students.

The research is discussed into five different sections including the introduction. Next to introduction, service quality from the point of the literature review is discussed to give an insight. Then, it is followed by the research design and methodology used for the study at hand. In the end, it encompasses the results and discussions accompanied by conclusion and recommendation for further research.

\section{Literature Review}

\subsection{Theoretical Review (Service Quality)}

Service quality is "the delivery of excellent or superior service relative to customer expectations" (Zeithaml and Bitner, 1996, p. 117). Service quality is recognized as a multi-dimensional construct. While the number of dimensions often varies from researcher to researcher, there is some consensus that service quality consists of three primary aspects: outcome quality, interaction quality, and physical service environment quality (Rust and Oliver, 1994; Brady and Cronin, 2001).

Outcome quality refers to the end result of the service received by the service seeker (Grönroos, 1984). Outcome quality reflects the customer's perception of the superiority of service experience (Brady and Cronin, 2001; Gro" nroos, 1982, 1984; Kang and James, 2004).

EJBE Vol. 6 No. $1 / 2016$ 
The interaction quality refers to the customers' evaluation of the service delivery process rendered by any tangible means (Grönroos, 1984). Interactive quality refers to the interaction between the service provider and the service seeker. It is a key element in evaluating the service quality as it will help the service seeker to observe and analyze the service provider' performance in lieu of the service delivered (Lehtinen and Lehtinen, 1991;_Grönroos, 1984, Rust and Oliver 1994).

Interaction quality (Grönroos, 1982, 1984) refers to the customers' perception of the manner in which the service is delivered during service encounters. Interaction quality is also related to customers' perception of the interactions with service providers (e.g. employees, staff, etc.) during service delivery (Brady and Cronin, 2001; Grönroos, 1982, 1984).

The physical environment quality measures the tangible aspect associated with the equipment and facilities pertaining to how the service is provided. That is, attitude of the service providing staffs, the communication equipment, computers, and photocopiers used to deliver the service (Grönroos, 1984)

A service firm may win its customer by meeting or exceeding their expectation through delivering consistently superior quality service than competitors do. These expectations of customers emanate through their past experience, friends or through promotional means. After receiving the services, customers evaluate the perceived service against their expectation; if the perceived service falls short of their expectation, the customers will be disappointed. However, if it meets or exceeds their expectation, they will be satisfied and keep on coming to the service provider.

The customer needs are fundamental for the enterprise to determine its internal capabilities to satisfy and retain its customer for the long- term sustainable business. In the interaction process, the customers are the sole players in the service delivery. They work hand in hand with the provider. The company has to work towards satisfying and work together with clients to create value for sustainable long term relationship (Brady and Cronin, 2001; Grönroos, 1982, 1984).

Customer satisfaction is a key ingredient on the service organization representing a customer evaluation of the trade- off between the service they received and the money paid for the service. Rust and Oliver (1994) were the first to define satisfaction as "the customer's fulfillment response" which is both an evaluation and an emotion-based response to a service. 


\section{Service Quality in Education}

Table 1: Literature review related to service quality

\begin{tabular}{|c|c|c|c|c|c|}
\hline Year & Author(s) & $\begin{array}{c}\text { No of } \\
\text { Dimensions }\end{array}$ & Details & Comments & Title \\
\hline 2013 & $\begin{array}{l}\text { Beom Joon Choi } \\
\text { Hyun Sik Kim }\end{array}$ & 6 & $\begin{array}{l}\text { Peer-to-peer quality, } \\
\text { Customer experience } \\
\text { quality, Outcome } \\
\text { quality, Interaction } \\
\text { quality, } \\
\text { Customer satisfaction, } \\
\text { Customer loyalty }\end{array}$ & $\begin{array}{l}\text { Except for changing of words, all the } \\
\text { item discussed are included in the five } \\
\text { dimensions introduced by the } \\
\text { Parasuraman et al (1988) }\end{array}$ & $\begin{array}{l}\text { The impact of outcome quality, } \\
\text { interaction quality, and peer-to- } \\
\text { peer quality on customer } \\
\text { satisfaction with a hospital service } \\
\text { (Managing Service Quality Vol. } 23 \\
\text { No. 3, } 2013 \text { pp. } 188-204\end{array}$ \\
\hline 2011 & Mik Wisniewski & 5 & $\begin{array}{l}\text { Tangibles, Reliability, } \\
\text { Responsiveness, } \\
\text { Empathy and Assurance }\end{array}$ & $\begin{array}{l}\text { Discussed the five dimensions } \\
\text { introduced by the Parasuraman et al } \\
(1988)\end{array}$ & $\begin{array}{l}\text { Using SERVQUAL to assess } \\
\text { customer satisfaction with public } \\
\text { sector services, (Managing service } \\
\text { quality volume } 11 \text {, number } 6,2011 \\
\text { pp 380-388) }\end{array}$ \\
\hline 2010 & $\begin{array}{l}\text { Prabha } \\
\text { Ramseook- } \\
\text { Munhurrun, } \\
\text { Soolakshna D. } \\
\text { Lukea-Bhiwajee, } \\
\text { Perunjodi Naidoo }\end{array}$ & 5 & $\begin{array}{l}\text { Tangibles, Reliability, } \\
\text { Responsiveness, } \\
\text { Empathy and Assurance }\end{array}$ & $\begin{array}{l}\text { Discussed the five dimensions } \\
\text { introduced by the Parasuraman et al } \\
\text { (1988) }\end{array}$ & $\begin{array}{l}\text { Service Quality In The Public } \\
\text { Service (International Journal of } \\
\text { Management and Marketing } \\
\text { Research } \diamond \text { Volume } 3 \diamond \text { Number } 1 \\
\$ 2010 \text { ) }\end{array}$ \\
\hline 2010 & $\begin{array}{l}\text { Lo Liang Kheng, } \\
\text { Osman Mahamad, } \\
\text { T. Ramayah, } \\
\text { Rahim Mosahab, }\end{array}$ & 4 & $\begin{array}{l}\text { Tangibles, Reliability, } \\
\text { Responsiveness, } \\
\text { Empathy, Assurance, }\end{array}$ & $\begin{array}{l}\text { Discussed the five dimensions } \\
\text { introduced by the Parasuraman et al } \\
\text { (1988) }\end{array}$ & $\begin{array}{l}\text { The Impact of Service Quality on } \\
\text { Customer Loyalty: A Study of } \\
\text { Banks in Penang, Malaysia } \\
\text { (International Journal of Marketing } \\
\text { Studies Vol. 2, No. 2; November } \\
\text { 2010) }\end{array}$ \\
\hline 2010 & $\begin{array}{l}\text { C.N Krishna Naik, } \\
\text { Swapna Nhargavi } \\
\text { Gantasala, } \\
\text { Gantasala } \\
\text { V.Prabhakar }\end{array}$ & 5 & $\begin{array}{l}\text { Reliability, Assurance, } \\
\text { Tangibles, Empathy and } \\
\text { Responsiveness }\end{array}$ & $\begin{array}{l}\text { Discussed the five dimensions introduced } \\
\text { by the Parasuraman et al (1988) }\end{array}$ & $\begin{array}{l}\text { Service Quality (Servqual) and its } \\
\text { Effect on Customer Satisfaction in } \\
\text { Retailing (European Journal of } \\
\text { Social Sciences - Volume 16, } \\
\text { Number } 2(2010) \text { ) }\end{array}$ \\
\hline
\end{tabular}

EJBE Vol. 6 No. 1/2016 


\section{Service Quality in Education}

\begin{tabular}{|c|c|c|c|c|c|}
\hline 2009 & Rakshit Negi & 5 & $\begin{array}{l}\text { Tangibles, Reliability, } \\
\text { Responsiveness, } \\
\text { Empathy, Assurance } \\
\text { Network aspect, and } \\
\text { Convenience }\end{array}$ & $\begin{array}{l}\text { Discussed the five dimensions } \\
\text { introduced by the Parasuraman et al } \\
\text { (1988) }\end{array}$ & $\begin{array}{l}\text { User's perceived service quality of } \\
\text { mobile communications: } \\
\text { experience from Ethiopia } \\
\text { (International Journal of Quality \& } \\
\text { Reliability Management, Vol. } 26 \\
\text { No. 7, } 2009 \text { pp. 699-711) }\end{array}$ \\
\hline 1996 & Francis Buttle & 5 & $\begin{array}{l}\text { Reliability, Assurance, } \\
\text { Tangibles, Empathy and } \\
\text { Responsiveness }\end{array}$ & $\begin{array}{l}\text { Discussed the five dimensions introduced } \\
\text { by the Parasuraman et al (1988) }\end{array}$ & $\begin{array}{l}\text { SERVQUAL: review, critique, } \\
\text { research agenda, European } \\
\text { Journal of Marketing }\end{array}$ \\
\hline 1996 & $\begin{array}{l}\text { Geoffrey Soutar } \\
\text { and } \\
\text { Margaret McNeil }\end{array}$ & 5 & $\begin{array}{l}\text { Reliability, Assurance, } \\
\text { Tangibles, Empathy and } \\
\text { Responsiveness }\end{array}$ & $\begin{array}{l}\text { Discussed the five dimensions introduced } \\
\text { by the Parasuraman et al (1988) }\end{array}$ & $\begin{array}{l}\text { Measuring service quality in a } \\
\text { tertiary institution. } \\
\text { Journal of Educational } \\
\text { Administration, Vol. } 34 \text { No. 1, } \\
\text { 1996, pp. 72-82. @ MCB } \\
\text { University Press }\end{array}$ \\
\hline 1994 & Rust and Oliver & 3 & $\begin{array}{l}\text { The customer- } \\
\text { employee (functional or } \\
\text { process quality) } \\
\text { interaction, The service } \\
\text { environment, and the } \\
\text { outcome quality } \\
\text { (technical quality) }\end{array}$ & $\begin{array}{l}\text { This is somehow similar to what Gronoos } \\
\text { and Lehitinen discussed with the } \\
\text { approach differs (service environment) }\end{array}$ & $\begin{array}{l}\text { Books on Service Quality: New } \\
\text { Directions in Theory and Practice, } \\
\text { year }=\{1994\} \\
\text { Sage Publications }\end{array}$ \\
\hline 1994 & $\begin{array}{l}\text { Clifford, Young, } \\
\text { Lawrence } \\
\text { Cunningham and } \\
\text { Moonkyu Lee }\end{array}$ & 5 & $\begin{array}{l}\text { Reliability, Assurance, } \\
\text { Tangibles, Empathy and } \\
\text { Responsiveness }\end{array}$ & $\begin{array}{l}\text { Discussed the five dimensions introduced } \\
\text { by the Parasuraman et al (1988) }\end{array}$ & $\begin{array}{l}\text { Assessing Service Quality as an } \\
\text { Effective Management Tool: The } \\
\text { Case of the Airline Industry } \\
\text { (Journal of Marketing Theory and } \\
\text { Practice, Vol. 2, No. } 2 \text { (Spring, } \\
\text { 1994), pp. 76-96) }\end{array}$ \\
\hline
\end{tabular}

EJBE Vol. 6 No. 1/2016

Page 53 


\section{Service Quality in Education}

\begin{tabular}{|c|c|c|c|c|c|}
\hline 1991 & $\begin{array}{l}\text { Lehtinen and } \\
\text { Lehtinen }\end{array}$ & 3 & $\begin{array}{lr}\text { Physical } & \text { quality, } \\
\text { Interactive } & \text { Quality and } \\
\text { Corporate } & \text { (image) } \\
\text { quality } & \end{array}$ & $\begin{array}{l}\text { These qualities are similar to Gronroos } \\
\text { model }\end{array}$ & $\begin{array}{l}\text { Two Approaches to Service } \\
\text { Quality Dimensions, The Service } \\
\text { Industries Journal, Vol } 11 \text { pp 287- } \\
\text { 303, Routledge }\end{array}$ \\
\hline $\begin{array}{l}1988, \\
1991 \\
1993\end{array}$ & $\begin{array}{l}\text { Parasuraman, } \\
\text { Zeithaml, and } \\
\text { Berry }\end{array}$ & 5 & $\begin{array}{l}\text { Reliability, Assurance, } \\
\text { Tangibles, Empathy and } \\
\text { Responsiveness }\end{array}$ & $\begin{array}{l}\text { The ten determinants of service quality } \\
\text { has been condensed to five by the authors }\end{array}$ & $\begin{array}{l}\text { SERVQUAL: A multiple - item } \\
\text { scale for measuring customer } \\
\text { perception of service quality, } \\
\text { Journal of Marketing, } 1988\end{array}$ \\
\hline 1988 & $\begin{array}{l}\text { Parasuraman and } \\
\text { Zeithaml }\end{array}$ & 5 & $\begin{array}{l}\text { Reliability, Assurance, } \\
\text { Tangibles, Empathy and } \\
\text { Responsiveness }\end{array}$ & The above same concepts discussed. & $\begin{array}{l}\text { "Communication and Control } \\
\text { Processes in the Delivery of } \\
\text { Service Quality," Journal of } \\
\text { Marketing, April 1988, pp. } 35-48 \text {. }\end{array}$ \\
\hline 1985 & $\begin{array}{l}\text { Parasuraman, } \\
\text { Zeithaml, and } \\
\text { Berry }\end{array}$ & 10 & $\begin{array}{l}\text { Reliability, } \\
\text { Responsiveness, } \\
\text { Competence, Access, } \\
\text { Communication, } \\
\text { courtesy, Credibility, } \\
\text { Security, } \\
\text { understanding/knowing } \\
\text { the customer, Tangibles }\end{array}$ & $\begin{array}{l}\text { The ten determinants of the service } \\
\text { quality as identified by Parasuraman, } \\
\text { Zeithaml, and Berry }\end{array}$ & $\begin{array}{l}\text { A Conceptual Model of Service } \\
\text { Quality and Its Implications for } \\
\text { Future Research (Journal of } \\
\text { Marketing, Vol. 49, No. } 4 \\
\text { (Autumn, 1985), pp. 41-50) }\end{array}$ \\
\hline 1984 & Gronroos & 3 & $\begin{array}{l}\text { Technical quality, } \\
\text { Functional Quality, and } \\
\text { Corporate image }\end{array}$ & $\begin{array}{l}\text { These dimensions are discussed by } \\
\text { Lehitinen and Lehitinen in a similar } \\
\text { fashion and emphasised on the image } \\
\text { propsed by Lehitnen }\end{array}$ & $\begin{array}{l}\text { A service quality model and its } \\
\text { marketing implications (European } \\
\text { Journal of marketing } 18 \text { (4), 36-44 }\end{array}$ \\
\hline
\end{tabular}

EJBE Vol. 6 No. 1/2016

Page 54 
Service Quality in Education

Consumer satisfaction has been considered the primary intervening constructs in the area of service marketing because ultimately they lead to the development of consumer loyalty or re-patronization of a product or service (e.g. Parasuraman et al, 1985, 1988; Rust \& Oliver, 1994; Zeithaml et al,1993, 1996).

Satisfaction or dissatisfaction has been called on the episodic measure in that it relates to the last service experience. Service quality is a global evaluation of all past service experiences. Research has found that customers' perceived evaluations of service quality have an impact on their level of satisfaction. Therefore, service quality evaluation is an antecedent to customer satisfaction.

Thus, the service rendering organization must prove it to its customer that its service is superior compared to its competitors through revolving around identifying and meeting its customer's needs. To do so, they shall focus or pursue a strategy in service marketing. That is, people (they shall hire a very knowledgeable working staff to deliver the service), process (they shall deliver prompt service within a short period of time), and physical evidence (they shall acquire modern equipment to show to customers that they are providing an excellent service).

\subsection{Empirical Literature: Service Quality}

Service quality can be measured by identifying the gaps between customers' expectations and their perceptions of the actual performance of service rendered by the service provider. Thus, service rendering organization should strive to narrow the gap between customer expectation and perception for the betterment and sustainability of their business.

The empirical literature of service quality is mainly dominated by the works of Parasuraman, Zeithamal and Berry (1988) who have built a 22-item instrument called SERVQUAL for measuring consumer perception of service quality. Servqual is an extensively acknowledged vital measurement tool used by many businesses (Airlines, shipping lines, Parcel service, health services, hotel, tourism, education, banks, logistics, etc.).

The tenet of servqual is originated on the dimensions of tangibility, responsiveness, reliability, empathy and assurance. The model accentuates to measure the gap between customers 'expectation of the services to be provided and their perception of the actual performance of services.

The five dimensions of service quality as identified by Parasuraman, Zeithaml, and Berry (1985) are of the following: Tangibles: the appearance of physical facilities, equipment, personnel and written materials. Reliability: The ability of 
an employee to perform the promised service dependably and accurately. Responsiveness: The willingness of an employee to help customers and provide prompt service. Assurance: The knowledge and courtesy of an employee's and their ability to inspire trust and confidence. Empathy: Caring and individualized attention given to customers.

\subsection{Conceptual Framework}

Parasuraman, Zeithaml, and Berry developed a popular scale called SERVQUAL to measure service quality across various service industries (Parasuraman et al., 1988).

The SERVQUAL model has been the most valuable instrument used to measure consumers' perceptions of service quality. The SERVQUAL scale consists of five dimensions, namely: tangibility, reliability, responsiveness, assurance and empathy and 22 items, (Parasuraman et al., 1988). The framework of SERVQAUL has been successfully adopted in many businesses (Airline, Shipping Line, Hotel, Hospital, Banking, Parcel, Education, etc.). SERVQUAL when applied to the tertiary level education can be interpreted in to the following:-

Tangibles: The appearance of physical facilities (lecture rooms, library, staff rooms), tools and equipment's (computers, internet, etc.) used to provide the service, appearance of personnel and communication materials.

> Reliability: The ability of the academic staffs to perform the promised service dependably and accurately. And their ability to discharge their duties consistently and dependably.

Responsiveness: The willingness and/ or readiness of the academic staffs to help students in counseling, assessing and submitting their grades promptly.

$>$ Assurance: The knowledge and courtesy of the academic staffs and their ability to convey trust and confidence: competence (possession of the required skills and knowledge to perform the service)

Empathy: The provision of caring, individualized attention to students: informing the students about the expectation of their performance, Understanding student's specific needs, and providing individualized attention. 
Service Quality in Education

\section{Figure 1: Conceptual framework of the study (Servqual Model)}

\section{Adapted from: (Parasuraman, Zeithaml, and Berry, 1988)}

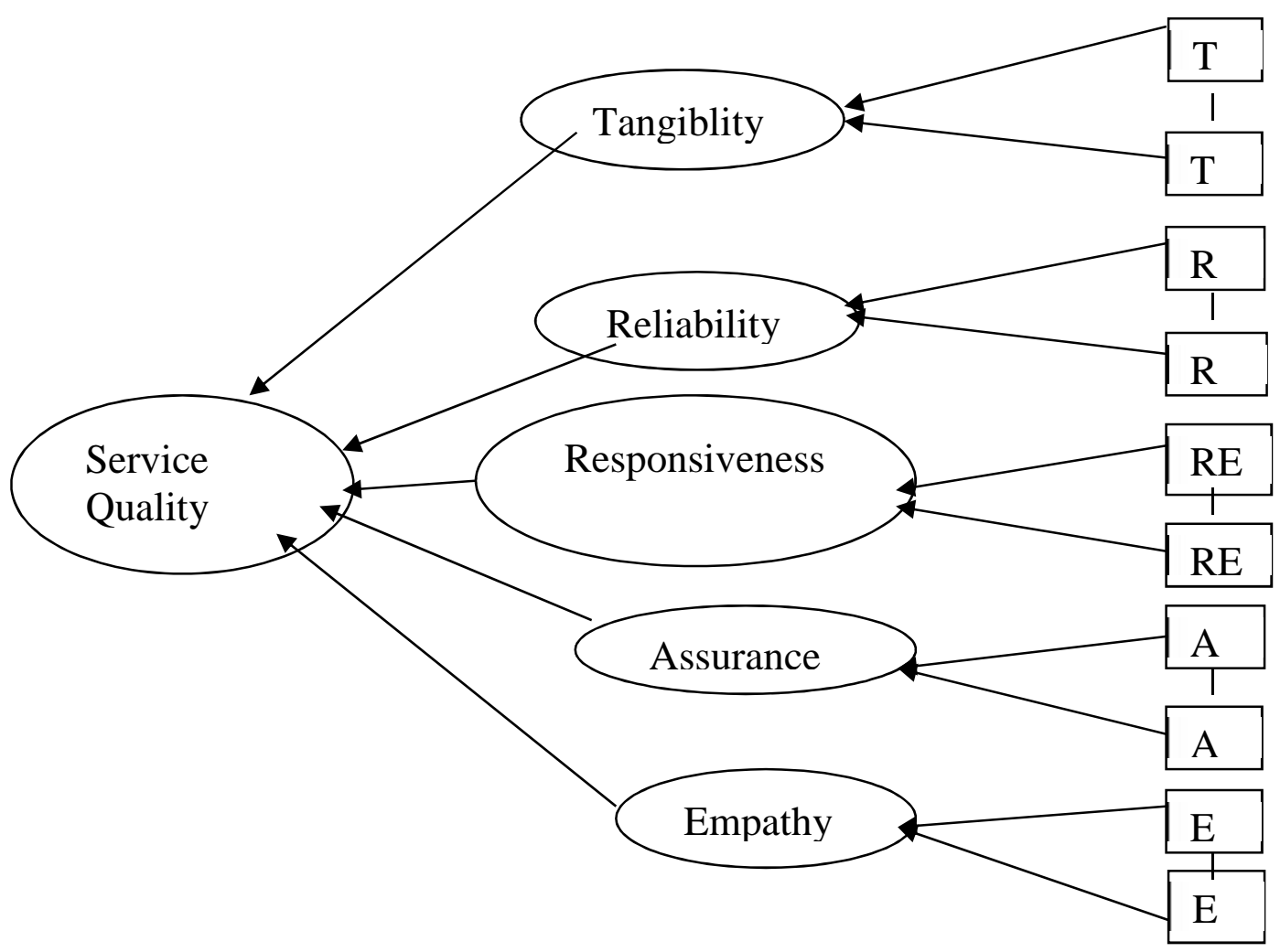

The other scholar who has dealt with the importance of service quality measurements include the works of Gronroos (1984) who suggested that service quality comprises of three dimensions, namely, the technical quality of the outcome of the service encounter, the functional quality of the process itself and the corporate image. In addition, Lehtinen and Lehtinen (1991) defined service quality as a three dimensional construct consisting of interactive, physical and corporate quality dimensions which are quite similar to Gronroos's view.

\section{Statement of the Problem}

Identifying and meeting customer needs is the sole objective of every organization. Satisfying and retaining customers require an eloquent approach and sustained commitment. Customer satisfaction occurs when organizations meticulously accomplish their duty to meet their customer needs and wants. Customer satisfaction is defined as "the number of customers, or percentage of total customers, whose reported experience with a firms products and services 
Service Quality in Education

exceeds specified satisfaction goals (Faris et al 2010). Customer satisfaction is crucial to sustainability, growth and profit for organization's supplying goods or services. Thus, better understanding of customers' perception helps companies to strategize the actions necessary to convene the customers' needs and wants. Customer satisfaction measures the overall performance of an organization in meeting the customers' expectation.

Thus, it is an eminent threat for business to fail to meet the customer perception of the service they are offering. Customer satisfaction is the sole and prominent asset for business to survive and maintain worthwhile growth.

The research has attempted to address the service quality of the Faculty of Business and Economics, Addis Ababa University. The research problem of the study has investigated the performances of the Faculty to its students' vis-a-viz Tangibility, Reliability, Responsiveness, Assurance, and Empathy.

\subsection{Research Questions}

The study has endeavored to find answers for the following research questions.

1. Do the physical facilities and equipment of the faculty are appealing to provide good service?

2. Do the faculty staffs perform the promised service dependably and accurately?

3. Do the faculty staffs provide timely and prompt service to customers?

4. Does the faculty have competent staffs to deliver the service to customers?

5. Do the staff of the faculty provide individualized attention to customers?

\section{Objectives of the Study}

The main objective of the study at hand is to measure the service quality provided by the Faculty of Business and Economics to its students. It strived to meet the following:

1. Identify the real causes that affect the service quality, and

2. Assess the customers' perception of the service quality of the faculty 


\section{Research Methodology}

\subsection{Research Approach}

The research adopts a Servqual model as a conceptual framework to elucidate the service quality of the Faculty of Business and Economics of the Addis Ababa University's extension students' of the academic year 2012 and 2013. The year 2012 and 2013 students have been selected due to the fact that they are in the system for more than two years and are expected to have exhibited gaps in the service delivery (add/drop, readmission, consultation, withdrawal, etc.).

\subsection{Sampling Technique}

A simple random sampling method has been used to ensure that all parts of the population are represented in the sample in order to increase the efficiency and decrease the error in the estimation. Thus, 20\% (100 students) out of the total 500 students' drawn from various disciplines (24\% Accounting, $24 \%$ Management, 20\% Public Administration, 16\% Economics and 16\% Informatics) are evenly apportioned and randomly has been selected. Out of the selected students, $86 \%$ of the questionnaire are duly filled and returned.

\subsection{Data Collection}

To gather information from randomly selected students, the study used both primary and secondary data sources. Primary data has been collected by using a standard close-end questionnaire using a five- point Likert scale where scores range from "strongly agree (5) and strongly disagree (1). And, secondary data has been collected from various journals published on the area.

\subsection{Data Analysis}

Descriptive statistics is used in analyzing the responses of the respondents. To this effect, statistical tool i.e. IBM SPSS version 20 is employed. 
Service Quality in Education

6. Results and Discussion

6.1 Distribution of Questionnaire

Table: 2 Distribution of Questionnaire

\begin{tabular}{llll}
\hline Departments & Distributed & $\begin{array}{l}\text { Duly filled and } \\
\text { returned }\end{array}$ & $\begin{array}{l}\text { Percentage of } \\
\text { response }\end{array}$ \\
\hline Economics & 20 & 15 & 75 \\
PADM & 20 & 19 & 95 \\
ACFN & 20 & 19 & 95 \\
Mangement & 20 & 17 & 85 \\
IT & 20 & 16 & 80 \\
Total & 100 & 86 & 86
\end{tabular}

As depicted in the above table, a total of 100 questionnaires evenly were distributed to the departments. Out of which, $86 \%$ of the questionnaire are dully filled and returned. The sample size is considered using purposive random sampling. That is, the study believed that the students' responses are much more alike.

\subsection{Respondents according to Gender}

Table 3: Respondents according to gender

\begin{tabular}{llllllll}
\hline Gender & \multicolumn{4}{c}{ Departments } & \multicolumn{3}{c}{ Total } \\
\cline { 2 - 8 } Male & 9 & 11 & 12 & 9 & 7 & 48 & 56 \\
Female & 6 & 8 & 7 & 8 & 9 & 38 & 44 \\
Total & 15 & 19 & 19 & 17 & 16 & 86 & 100 \\
\hline
\end{tabular}

As illustrated in the above table, $56 \%$ of the respondents are male while the remaining $44 \%$ are female. However, this percentage of response has no significance in the analysis. It has been incorporated simply to show the representation of the respondents among the sample. 
Service Quality in Education

\subsection{Respondents according to their academic year of enrollment}

Table 4: Respondents according to year of enrollment

\begin{tabular}{llllllll}
\hline \multicolumn{1}{l}{$\begin{array}{l}\text { Year of } \\
\text { Enrollment }\end{array}$} & \multicolumn{4}{c}{ Departments } & \multicolumn{3}{c}{ Total } \\
\cline { 2 - 8 } $\mathbf{2 0 1 2}$ & ECON & PADM & ACFN & MGMT & IT & Num & $\%$ \\
$\mathbf{2 0 1 3}$ & 15 & 19 & & & & 34 & 40 \\
Total & & & 19 & 17 & 16 & 52 & 60 \\
& 15 & 19 & 19 & 17 & 16 & 86 & 100 \\
\hline
\end{tabular}

As seen in the above table, $40 \%$ of the respondents are enrolled in the year 2012 while the remaining $60 \%$ are enrolled in the year 2013. The rationale behind choosing these batches is due to the fact that they are in the system for more than a year. Thus, these batches can provide a valuable and constructive feedback on the service (Add/Drop, Readmission, Course Waiver, Advising, Complaints, etc.) the university provides. Comparatively, more students enrolled in the year 2013 have been chosen considering their exposure and anticipating a more sound response on the service the university renders.

\subsection{Discussions}

The constructs which are used in this research are reported in Table5. The table includes the variables, the number of items considered under each construct, mean, standard deviation, the reliability test-alpha. In order to have a valid construct in the model, each of the items comprising the construct was checked to see if it was uni-dimensional. To this effect, each construct was then evaluated using a separate reliability test and the Cronbach's alpha is reported in the same table. The Cronbach's alpha measures how well a set of items (variables) in the measures of a single uni-dimensional latent construct was also tested. When data have a multidimensional structure, Cronbach's alpha is usually low. The higher the alpha value is the better the data reliability (Field, 2009). Most of the constructs are good for students; with few exceptions, such as empathy (alpha is equal to 0.598 ) and assurance (alpha is equal to 0.672).

Though the commonly accepted level of Alpha is 0.60 (Joseph et.al, 2010), the finding showed that, apart from one construct (that is empathy- less than or equal to 0.60), all have a Cronbach's Alpha value greater than or equal to 0.6. Moreover, all of the items under each construct have a factor loading greater than or equal to 0.50 and inter-item-total correlation greater than or equal to 0.30 
Service Quality in Education

(Evans et.al, 1996). The descriptive statistics of each item under each construct/variable are reported in table4.

Table5 : Over all mean and standard deviation of the construct

\begin{tabular}{|l|l|l|l|l|l|l|l|}
\hline & \multicolumn{3}{|c|}{} & \multicolumn{7}{|c|}{ Students } \\
\hline SN & & $\begin{array}{l}\text { \# of } \\
\text { Items }\end{array}$ & $\begin{array}{l}\text { Cronb. } \\
\text { Alpha }\end{array}$ & N & Sum & Mean & $\begin{array}{l}\text { Std. } \\
\text { Dev. }\end{array}$ \\
\hline 1 & Tanstruct & 7 & 0.678 & 87 & 241.43 & 2.80 & .681 \\
\hline 2 & Reliability & 4 & 0.761 & 87 & 237.00 & 2.72 & .895 \\
\hline 3 & Responsiveness & 5 & 0.723 & 87 & 210.70 & 2.42 & .773 \\
\hline 4 & Assurance & 3 & 0.672 & 87 & 249.00 & 2.86 & .851 \\
\hline 5 & Empathy & 3 & 0.598 & 86 & 224.00 & 2.60 & .786 \\
\hline
\end{tabular}

As shown in Table5, the overall mean and standard deviation of the construct tangibility is found to be 2.80 and 0.681 . That is, the higher mean and relatively low standard deviation show that the tangibility of the service rendered by the FBE with respect to students' need is relatively good. A close investigation of each item as under the construct responsiveness, shown in Table6 supports this finding. All the items, except "you have an access to a computer to aid your learning at FBE? "have got a low mean (less than 2.50) and high standard deviation (greater than 1.00). From Table 6, one item out of the total seven items that measure the construct tangibility are rated by more than $40 \%$ of the students either strongly disagree or disagree. From the findings, relatively very few numbers of students have strongly agreed for these items. 
Service Quality in Education

Table 6: Tangibility

\begin{tabular}{|c|c|c|c|c|c|c|c|c|c|c|}
\hline $\mathbf{S N}$ & Tangibility & Mean & Stdv. & $\mathbf{N}$ & SDA & DA & $\mathbf{N}$ & $\mathbf{A}$ & SA & Total \\
\hline & & & & & $\mathrm{N}(\%)$ & $\mathrm{N}(\%)$ & $\mathrm{N}(\%)$ & $\mathrm{N}(\%)$ & $\mathrm{N}(\%)$ & $\mathrm{N}(\%)$ \\
\hline 1 & $\begin{array}{l}\text { An orientation is given to } \\
\text { you the first time you } \\
\text { enroll at FBE? }\end{array}$ & 3.01 & 1.38 & 87 & $21(23.6)$ & $11(12.4)$ & $13(14.6)$ & $32(36)$ & $10(11.2)$ & $87(97.8)$ \\
\hline 2 & $\begin{array}{l}\text { The commitment of FBE in } \\
\text { improving the quality of } \\
\text { education is high? }\end{array}$ & 2.73 & 1.19 & 86 & $16(18)$ & $20(22.5)$ & $28(31.5)$ & $15(16.9)$ & $7(7.9)$ & $86(96.6)$ \\
\hline 3 & $\begin{array}{l}\text { Are you provided with } \\
\text { quality and recent books in } \\
\text { FBE libraries? }\end{array}$ & 2.78 & 1.25 & 86 & $19(21.3)$ & $16(18)$ & $21(23.6)$ & $25(28.1)$ & $5(5.6)$ & $86(96.6)$ \\
\hline 4 & $\begin{array}{l}\text { You have an access to a } \\
\text { computer to aid your } \\
\text { learning at FBE? }\end{array}$ & 2.28 & 1.09 & 86 & $26(29.2)$ & $26(29.2)$ & $18(20.2)$ & $16(18)$ & & $86(96.6)$ \\
\hline 5 & $\begin{array}{l}\text { The administration of final } \\
\text { exams at FBE is well } \\
\text { organized and strictly } \\
\text { controlled? }\end{array}$ & 2.99 & 1.19 & 86 & $15(16.9)$ & $10(11.2)$ & $28(31.5)$ & $27(30.3)$ & $6(6.7)$ & $86(96.6)$ \\
\hline 6 & $\begin{array}{l}\text { The class size of students } \\
\text { to sections at FBE is more } \\
\text { appropriate and } \\
\text { manageable? }\end{array}$ & 3.17 & 1.06 & 86 & $7(7.9)$ & $16(18)$ & $23(25.8)$ & $35(39.3)$ & $5(5.6)$ & $86(96.6)$ \\
\hline 7 & $\begin{array}{l}\text { The normal curve grading } \\
\text { system of FBE is more } \\
\text { evaluative and effective? }\end{array}$ & 2.67 & 1.02 & 86 & $15(16.9)$ & $18(20.2)$ & $33(37.1)$ & $20(22.5)$ & & $86(96.6)$ \\
\hline
\end{tabular}

EJBE Vol. 6 No. 1/2016

Page 63 
Service Quality in Education

As shown in Table 5, the overall mean and standard deviation of the construct reliability is found to be 2.72 and 0.895 . From this, one can infer that the reliability of the service rendered by FBE is relatively good. However, close investigations of each item as under the construct reliability, shown in Table7 indicates that. Almost all the items, except item "the students hand book is very informative and applicable and the instructor at FBE encourages students to be active participants?" have got high mean (greater than 2.75) and high standard deviation (greater than1.20). From Table 6, all the four items that measure the construct reliability are rated by more than $20 \%$ of the students as neutral. From the findings, relatively very few numbers of students have strongly agreed and agreed for all the items.

Table 7: Reliability

\begin{tabular}{|c|c|c|c|c|c|c|c|c|c|c|}
\hline SN & Reliability & Mean & Stdv & $\mathrm{N}$ & SDA & DA & $\mathrm{N}$ & A & SA & Total \\
\hline & & & & & $\mathrm{N}(\%)$ & $\mathrm{N}(\%)$ & $\mathrm{N}(\%)$ & $\mathrm{N}(\%)$ & $\begin{array}{c}\mathrm{N} \\
(\%)\end{array}$ & $\mathrm{N}(\%)$ \\
\hline 1 & $\begin{array}{l}\text { The student } \\
\text { hand book is } \\
\text { very } \\
\text { informative } \\
\text { and } \\
\text { applicable? }\end{array}$ & 2.85 & 1.22 & 87 & 17(19) & $14(16)$ & $27(30)$ & $23(26)$ & $6(7)$ & $87(98)$ \\
\hline 2 & $\begin{array}{l}\text { The } \\
\text { instructors } \\
\text { at FBE } \\
\text { encourage } \\
\text { students to } \\
\text { be active } \\
\text { participants? }\end{array}$ & 2.90 & 1.22 & 86 & $13(14.6)$ & $21.0(23.6)$ & $22(24.7)$ & $22(24.7)$ & $8(9)$ & $86(96.6)$ \\
\hline 3 & $\begin{array}{l}\text { The } \\
\text { teaching - } \\
\text { learning } \\
\text { quality at } \\
\text { FBE is very } \\
\text { good? }\end{array}$ & 2.62 & 1.14 & 86 & $16(18)$ & $24(27)$ & $29(32.6)$ & $11(12.4)$ & $6(6.7)$ & $86(96.6)$ \\
\hline 4 & $\begin{array}{l}\text { The } \\
\text { evaluation } \\
\text { modality at } \\
\text { FBE is very } \\
\text { good? }\end{array}$ & 2.59 & 1.06 & 86 & $12(13.5)$ & $33(33.71)$ & $22(24.7)$ & $16(18)$ & $3(3.4)$ & $86(96.6)$ \\
\hline
\end{tabular}

As shown in Table5, the overall mean and standard deviation of the construct responsiveness is found to be 2.42 and 0.773 . That is, the low mean and relatively high standard deviation show that the responsiveness of FBE with respect to students' need is relatively low. A close investigation of each item as under the construct responsiveness, shown in Table 8 supports this finding. 
Almost all the items, except item "You have a good access to advisors when facing academic problems?" have got high mean (greater than 2.50) and low standard deviation (less than 1.00). From Table 8 , four out of the five items that measure the construct responsiveness are rated by more than $50 \%$ of the students either strongly disagree or disagree. From the findings relatively very few numbers of students have strongly agreed for all items.

\section{Table8. Responsiveness}

\begin{tabular}{|c|c|c|c|c|c|c|c|c|c|}
\hline No & Responsiveness & Mean & Stdv & SDA & DA & $\mathbf{N}$ & $\mathbf{A}$ & SA & Total \\
\hline 1 & $\begin{array}{l}\text { FBE provides you } \\
\text { with the student } \\
\text { hand books which } \\
\text { give you all the } \\
\text { information that } \\
\text { you require? }\end{array}$ & 2.33 & 1.19 & $27(30.33)^{*}$ & $27(30.30)$ & $11(12.40)$ & $21(23.60)$ & $1(1.10)$ & $87(97.87)$ \\
\hline 2 & $\begin{array}{l}\text { The } \\
\text { Administration is } \\
\text { so responsive to } \\
\text { students' quest }\end{array}$ & 2.30 & 1.19 & $33(37.08)$ & 13(14.61) & $24(27.00)$ & $16(17.98)$ & $1(1.10)$ & $87(97.87)$ \\
\hline 3 & $\begin{array}{l}\text { You have a good } \\
\text { access to advisors } \\
\text { when facing } \\
\text { academic } \\
\text { problems? }\end{array}$ & 2.78 & 0.98 & $3(3.37)$ & $39(43.82)$ & $22(24.70)$ & $18(20.22)$ & 4(4.49) & $86(96.63)$ \\
\hline 4 & $\begin{array}{l}\text { The decision } \\
\text { making process at } \\
\text { FBE is highly } \\
\text { transparent? }\end{array}$ & 2.45 & 1.13 & $20(22.47)$ & $28(31.46)$ & $20(22.50)$ & $15(16.85)$ & $3(3.37)$ & $86(96.63)$ \\
\hline 5 & $\begin{array}{l}\text { Your } \\
\text { involvement/active } \\
\text { participation in the } \\
\text { decision making } \\
\text { process of FBE is } \\
\text { very high? }\end{array}$ & 2.28 & 1.09 & $26(29.21)$ & $23(25.84)$ & $27(30.30)$ & 7(7.87) & $3(3.34)$ & $86(96.63)$ \\
\hline
\end{tabular}

*27(30.33), 27 observation, and 30.33 percentage out of the total (once you put this on the first table you do not need to repeat it)

As shown in Table 5, the overall mean and standard deviation of the construct assurance is found to be 2.86 and 0.851 . From this finding one can infer that the assurance of FBE with respect to students' need is relatively good. A close investigation of each item as under the construct assurance, shown in Table 9, supports this finding. Almost all the items, except item "You are encouraged to become an active learner at FBE?" have got relatively high mean (greater than 2.5) and low standard deviation (less than 1.00). From Table 9, all of the three items that measure the construct assurance are rated moderately higher by the 
Service Quality in Education

students either strongly agree or agree. From the findings relatively very few numbers of students have strongly disagreed or disagree for all the items and many have rated neutral.

Table 9: Assurance

\begin{tabular}{|c|c|c|c|c|c|c|c|c|c|c|}
\hline SN & Assurance & Mean & Stdv. & $\mathrm{N}$ & SDA & DA & $\mathrm{N}$ & A & SA & Total \\
\hline & & & $\mathrm{N}(\%)$ & & $\mathrm{N}(\%)$ & $\mathrm{N}(\%)$ & $\mathrm{N}(\%)$ & $\mathrm{N}(\%)$ & $\begin{array}{c}\mathrm{N} \\
(\%)\end{array}$ & $\mathrm{N}(\%)$ \\
\hline 1 & $\begin{array}{l}\text { Are you } \\
\text { encouraged to } \\
\text { become an active } \\
\text { learner at FBE? }\end{array}$ & 2.88 & 0.90 & 86 & $5(5.6)$ & $20(22.5)$ & $16(51.7)$ & $10(11.2)$ & $5(5.6)$ & $86(96.6)$ \\
\hline 2 & $\begin{array}{l}\text { The instructors at } \\
\text { FBE are competent } \\
\text { enough in } \\
\text { delivering the } \\
\text { lecture? }\end{array}$ & 2.98 & 1.15 & 86 & $13(14.6)$ & $14(15.7)$ & $25(28.1)$ & $30(33.7)$ & $4(4.5)$ & $86(96.6)$ \\
\hline 3 & $\begin{array}{l}\text { The methodology } \\
\text { engaged in } \\
\text { teaching at FBE is } \\
\text { very good? }\end{array}$ & 2.75 & 1.20 & 86 & $17(19.1)$ & $20(22.5)$ & $23(25.8)$ & $22(24.7)$ & $5(5.6)$ & $87(97.8)$ \\
\hline
\end{tabular}

As shown in Table 4, the overall mean and standard deviation of the construct empathy is found to be 2.60 and 0.786 . From this finding one can infer that, the empathy, the concern that the FBE has in regard to resolving the students' problem is high. A close investigation of each item as under the construct empathy, shown in Table 7 shows that almost all the items, except item "FBE provides instant solutions to students' problems?" have got low mean (less than 2.50) and low standard deviation (less than 1.00). From Table 9, all the three items that measure the construct empathy are rated by more than $30 \%$ of the students either strongly disagree or disagree. From the findings, relatively very few numbers of students have strongly agreed and many of the students are neutral for all the items. 
Service Quality in Education

Table 10: Empathy

\begin{tabular}{|c|c|c|c|c|c|c|c|c|c|c|}
\hline SN & Empathy & Mean & Stdv & $\mathrm{N}$ & SDA & DA & $\mathrm{N}$ & A & SA & Total \\
\hline & & & & & $\mathrm{N}(\%)$ & $\mathrm{N}(\%)$ & $\mathrm{N}(\%)$ & $\mathrm{N}(\%)$ & $\begin{array}{c}\mathrm{N} \\
(\%)\end{array}$ & $\mathrm{N}(\%)$ \\
\hline 1 & $\begin{array}{l}\text { FBE provides } \\
\text { instant solutions } \\
\text { to students' } \\
\text { problems? }\end{array}$ & 2.34 & 0.95 & 86 & $20(22.5)$ & $26(29.2)$ & $31(34.8)$ & $9(10.1)$ & & $86(96.6)$ \\
\hline 2 & $\begin{array}{l}\text { The admission } \\
\text { procedure at } \\
\text { FBE is very } \\
\text { good? }\end{array}$ & 2.64 & 1.12 & 86 & $15(16.9)$ & $26(29.2)$ & $23(25.8)$ & $19(21.3)$ & $3(3.4)$ & $86(96.6)$ \\
\hline 3 & $\begin{array}{l}\text { The add/drop } \\
\text { procedure of } \\
\text { FBE is more } \\
\text { efficient and } \\
\text { effective? }\end{array}$ & 2.84 & 1.08 & 86 & $12(13.5)$ & $18(20.2)$ & $32(36)$ & $20(22.5)$ & $4(4.5)$ & $86(96.6)$ \\
\hline
\end{tabular}

\section{Conclusion}

Based on the data and findings, the following conclusions are drawn. Poor teaching modality designed is contributory to poor service and inferior quality outcome. Thus, quality of service is determined by maintaining timeliness of services and responds to customers' quest immediately through providing prompt service. In addition, the participation of students' in the teachinglearning process is an indispensable factor in elevating them with profound knowledge. Also, provision of caring and giving individual attention in the service delivery is of a paramount importance for service rendering institutions. Furthermore, the overall quality of the teaching- learning is determined by the physical infrastructure available for delivering the same.

To this effect, the overall performance of FBE in maintaining educational service quality is good. However, the responsiveness of FBE in providing prompt service to students is very low. To this end, transparent approach to provide instant solution to student's problem by developing a new one or modifying an existing policy through a coordinated effort with students', instructors' registrar, supporting service units, etc., is indispensable. Further more, management of FBE has to set a system to closely follow up the students' problem to provide prompt service.

Further improvement in certain constructs under empathy, assurance, tangibility and reliability must be revisited. 
Service Quality in Education

\section{References}

Ana Brochado Comparing alternative instruments to measure service quality in higher education, Quality Assurance in Education Vol 17 No 2, 2009 pp, 174-190, Emerald.

Berry, LL., A. Parasuraman, Valarie A. Zeithaml, Dennis Adsit, John Hater, Eric J. Vanetti, David J. Veale (1994) “Improving Service Quality in America: Lessons Learned [and Executive Commentary]", The Academy of Management Executive Vol. 8, No. 2, pp. 32- 52.

Birgit Leisen Pollack, (2008) "The nature of the service quality and satisfaction relationship: Empirical evidence for the existence of satisfiers and dissatisfiers", Managing Service Quality, Vol. 18 Iss: 6, pp.537 - 558.

Brady, M.K, \& J. Cronin,(2001)," Some New Thoughts on Conceptualizing Perceived Service Quality: A Hierarchical Approach ", The Journal of Marketing, Vol. 65 No.3 , pp.34-49.

Christian Grönroos: A Service Quality Model and its Marketing Implications 1984, European Journal of Marketing.

DEBBIE CLEWES, A Student-centred Conceptual Model of Service Quality in Higher Education, Quality in Higher education, 9:1, 69-85, DOI

Evans, M., Moutinho, L, \& Van Raaij, W. F. 1996. Applied Consumer Behavior, Addison-Wesley Publishing Ltd.

Field, A. 2009. Discovering Statistics using SPSS (3rd ed.), SAGE Publications, London.

Filipa Fonseca, Sofia Pinto, Carlos Brito, "Service Quality and Customer Satisfaction in Public Transports", International Journal for Quality research, Vol.4, No. 2, 2010. 
Francis Buttle, (1996) "SERVQUAL: review, critique, research agenda", European Journal of Marketing, Vol. 30 Iss: 1, pp.8 - 32.

Francis Buttle, SERVQUAL: review, critique Research Agenda, European Journal of marketing, December 1995 , Vol.30 No1, 1996, pp. 8-32.

Geoffrey Soutar and Margaret McNeil:Measuring service quality in a tertiary institution.Journal of Educational Administration, Vol. 34 No. 1, 1996, pp. 72-82.

GI-Du Kang and Jeffrey James: Service quality dimensions: and examination of Gro nroos's service quality model Managing Service Quality Volume $14 \cdot$ Number $4 \cdot 2004 \cdot$ pp. 266-277.

Halil Nadiri, Jay Kandampully and Kashif Hussain, Students' perceptions of service quality in higher education, Total Quality Management, Vol. 20 No. 5 May 2009, 525-535,

Joseph, F.H. William, C.B. \& Barry, J. B. 2010. Multivariate Data Analysis (7th ed.), Pearson Education/Prentice Hall.

Lo Liang Kheng, Osman Mohamad, T.Ramayah, Rahim Mosahab : The impact of Service Quality on Customer Loyalty: A study of Banks in Penang, Malaysia, International Journal of Marketing Studies Vol. 2 No2. , November 2010.

Mohammad Mahdi Tavakoli and Hadi Shirouyehzad* , Reza Dabestani:Efficiency evaluation of a private bank's branches with service quality approach by data envelopment analysis nt. J. Services and Operations Management, Vol. 16, No. 4, 2013. 
Service Quality in Education

Ms U.Dhanalakshmi, Dr. R. Rajini, Ms S.Kanimozhi: Developing Service quality Using Gap Model- A critical study Journal of Business and Management PP 46-51.

Naik, C.N Krishna, Swapna Bhargavi Gantasala, Gantasala V. Prabhakar: Service Quality: (Servqual) and its Effect on Customer Satisfaction in Retailing, European Journal of Social Sciences - Volume 16, Number 2 (2010).

Parasuraman, A., Zeithaml, V., Berry, L.L. (1988), "SERVQUAL: a multipleitem scale for measuring consumer perceptions of service quality", Journal of Retailing, Vol. 64 pp.12-40.

Parasuraman, Valarie A. Zeithaml, Leonard L. Berry “Reassessment of Expectations as a Comparison Standard in Measuring Service Quality": The Journal of Marketing, Vol. 58, No. 1 (Jan., 1994), pp. 111-124.

Parasurman A, A. Zeithmal, V.A. and Berry, L.L (1985), “A conceptual Model of Service Quality and Its Implication for Future Research", Journal of Marketing, pp 41-50.

Paul G. Patterson, Richard A. Spreng: Modeling the relationship between perceived value, satisfaction and repurchase intentions in a business-tobusiness, services context, International Journal of Service Industry Management, 1997.

Paul W. Farris, Neil T. Bendle, Phillip E. Pfeifer, David J. Reibstein, (2010), marketing metrics: The Definitive Guide to Measuring Marketing Performance/ Paul W. Farris ... [et al.], .2nd Edition, 2010 by Pearson Education, Inc. Upper Saddle River, New Jersey 07458

Philip Kotler, Veronica Wong, John Saunders, and Gary Armstrong, Principles of Marketing, Fourth European Edition, Prentice Hall, Page 625. 
Roland T. Rust, Richard L. Oliver Service Quality: New Directions in Theory and Practice, 1994.

Roland T. Rust, Richard L. Oliver, Service Quality: Insights and Managerial Implications from the Frontier. 1994.

S.M. Zabed Ahmed, Md. Zahid Hossain Shoeb, (2009) "Measuring service quality of a public university library in Bangladesh using SERVQUAL", Performance Measurement and Metrics, Vol. 10 Iss: 1, pp.17 - 32.

Tewodros Wuhib, (1999): Service Marketing text, first edition, Alpha University College.

Valarie A. Zeithaml, Amy R. Hubbert, William T. Faranda, Mary Jo Bitner: Customer contributions and roles in service delivery, International Journal of Service Industry Management, 1997.

Zeithaml, V.A., Berry, L.L., Parasuraman, A. (1991), "The nature and determinants of customer expectations of service", Marketing Science Institute, Cambridge, MA., working paper 91-113.

Zelthmal A., \& Bitner M. (2006), Service Marketing -Integrating Customer Focus Across the firm), $3^{\text {rd }}$ ed. Tata MacGraw-Hill. Publishing Company Limited, New Delhi. 